DA-2003, núms. 265-266. JESÚS JORDANO FRAGA. Ciencia, Tecnología, medio ambiente y respons...

Jesús Jordano Fraga

Profesor Titular de Derecho Administrativo

Universidad de Sevilla

\title{
Ciencia, tecnología, medio ambiente y responsabilidad patrimonial de la Administración: en especial, los denominados riesgos del desarrollo ${ }^{1}$
}

SUMARIO: I. INTRODUCCIÓN. II. LOS RIESGOS TECNOLÓGICOS Y LA RESPONSABILIDAD DE LA ADMINISTRACIÓN: LA EXONERACIÓN POR RIESGOS DEL DESARROLLO. A) TESIS: LA NORMA ES CONSTITUCIONAL. 1. La nueva previsión se inserta en la antijuricidad (GARCÍA DE ENTERRÍA, FERNÁNDEZ RODRÍGUEZ, MARTÍN REBOLLO, LÓPEZ MENUDO). 2. La nueva previsión, especificación de la fuerza mayor, está en manos del legislador no conculcando la Constitución el artículo 141.1 de la Ley 30/1992. 3. La nueva previsión salva su constitucionalidad por su último inciso: (MONTORO CHINER). B) ANTÍTESIS. 1. La exclusión de responsabilidad en riesgos del desarrollo es indeseable (ESTEVE PARDO, GOLDENBERG). 2. La exención de responsabilidad operada por el artículo 141.1 de la Ley 30/1992 como norma inconstitucional o contraria al Derecho de la Unión Europea (LEGUINA VILLA, SALVADOR CODERCH, MARÍN LÓPEZ). 3. Nuestra posición. C). SÍNTESIS: ELEMENTOS PARA UN DEBATE. III. RESPONSABILIDAD POR DAÑOS AL MEDIO AMBIENTE Y RESPONSABILIDAD DE LA ADMINISTRACIÓN. A) LOS RIESGOS TECNOLÓGICOS Y LAS Administraciones Públicas. El principio de PRECaUCión o CaUtela. B) La PROPUESTA REGULACIÓN DE LA RESPONSABILIDAD POR DAÑOS AL MEDIO AMBIENTE.

\section{INTRODUCCIÓN}

El presente estudio nace de la amable invitación del Prof. BASSOLS COMA. Sería injusto comenzar sin agradecer públicamente

1 Estudio realizado en el marco del proyecto CEC 2001-3160, «Régimen jurídico de los recursos naturales», subvencionado por la DGI (Secretaría de Estado de Política Científica, Ministerio de Ciencia y Tecnología).

Documentación Administrativa / nº. 265-266 (enero-agosto 2003) 
DA-2003, núms. 265-266. JESÚS JORDANO FRAGA. Ciencia, Tecnología, medio ambiente y respons...

esta invitación. Tampoco sería de recibo comenzar sin expresar mi admiración por el Prof. BASSOLS COMA, inmenso administrativista. Para mí es un privilegio recibir su profundo magisterio jurídico y humano.

En una sociedad tecnológica, la posibilidad de producción de daños masivos con incidencia en el medio ambiente es un hecho. En este contexto, la Administración sigue dominando el desarrollo social actuando directa o indirectamente. La Administración en la sociedad de nuestros días es la ejecutora de los grandes proyectos (infraestructuras) y es la prestadora de los grandes servicios públicos por el momento (transporte ferroviario, puertos, aeropuertos, sanidad). La Administración también regula los procesos tecnológicos que comportan o pueden comportar riesgos (estableciendo niveles admisibles de emisión e inmisión $)^{2}$. La Administración autoriza actividades que representan riesgos (grandes industrias, gestores de residuos) y en el ejercicio de la potestad de evaluación determina el condicionado ambiental de proyectos sujetos a técnicas de prevención ambiental; la Administración previene y controla riesgos mediante la protección civil. Es claro que todo este núcleo de actividades descritas pueden dar lugar a daños. El desafío es saber en qué supuestos y con qué alcance puede tener entrada la responsabilidad patrimonial de las Administraciones Públicas. La admisión de la exoneración por riesgos del desarrollo introducida por la Ley 4/1999, de 13 de enero, de modificación de la Ley 30/1992, de 26 de noviembre, incorpora elementos decisivos en esa respuesta y ha generado un debate doctrinal que merece una reflexión. El principio de cautela también se presenta como un referente en esta materia pues su entrada en juego puede evitar precisamente cualquier generación de daños. Por otro lado, en el horizonte normativo se atisba la próxima regulación de la responsabilidad por daños al medio ambiente planteando retos transformadores de nuestro ordenamiento jurídico. Todo este amplio núcleo de cuestiones constituye el objeto del presente estudio.

2 Así, por ejemplo, Montoro Chiner cree que los hechos o circunstancias que no se hubiesen podido prever o evitar, según el estado del conocimiento o de la ciencia, han de ponerse en relación con la posible omisión antijurídica del poder público: «siempre que fuere razonable esperar de la Administración una actuación en un sentido concreto que evite daños a las personas o a sus bienes, la circunstancia imprevisible o inevitable -según el actual conocimiento- deja de ser fuerza mayor para convertirse en caso de responsabilidad por omisión o por inactividad. Desde esta perspectiva, en su opinión, la contaminación electromagnética, el consumo de productos transgénicos y otros tantos supuestos en materia alimentaria y ambiental, relacionados con el riesgo de aplicación de las nuevas tecnologías, constituirían ejemplos a plantear (Responsabilidad patrimonial de la Administración y contrato de seguro, Atelier administrativo, Barcelona 2002, p. 25 y nota $\mathrm{n}^{\mathrm{o}} 6$ ). 


\section{LOS RIESGOS TECNOLÓGICOS Y LA RESPONSABILIDAD DE LA ADMINISTRACIÓN: LA EXONERACIÓN POR RIESGOS DEL DESARROLLO}

El apartado 1, del artículo 141 de la Ley 30/1992, de 26 de noviembre, en su redacción dada por la Ley 4/1999, determina, como es sabido, que «No serán indemnizables los daños que se deriven de hechos o circunstancias que no se hubieren podido prever o evitar según el estado de los conocimientos de la ciencia o de la técnica existentes en el momento de la producción de aquellos, todo ello sin perjuicio de las prestaciones asistenciales o económicas que las leyes puedan establecer para estos casos». Y el fundamento de esta nueva regulación es el siguiente, según la exposición de motivos de la Ley 4/1999:

"En el art. 141 se matizan los supuestos de fuerza mayor que no dan lugar a responsabilidad, y, en beneficio del afectado, se prevé la actualización de la cuantía de la indemnización».

La STS de 31 de mayo de 1999, Ar. $6154^{3}$, Sala $3^{\text {a }}$, Sección $6^{\text {a }}$, Ponente González Navarro, ha procedido a interpretar preliminarmente la causa de exoneración introducida por la Ley 4/1999. Sin cuestionar la constitucionalidad del precepto, y sin aplicarlo al caso concreto (el art. 141 era inaplicable a un supuesto anterior previo a la Ley 4/1999), sienta claves interpretativas que, sin duda, van a influir en su futura aplicación. La doctrina sentada por esta sentencia puede sintetizarse así:

1. No basta con que se invoque la insuficiencia de unos conocimientos científicos en la materia de que se trate, sino que es necesario que ese estado insatisfactorio de la ciencia se pruebe, prueba que en el caso -y por estricta aplicación de las reglas de la carga de la prueba- tiene que hacer la Administración [Fundamento de Derecho 5º B a)].

2. No es estado de la legislación. Para probar dicho estado no bastará normalmente con argumentar sobre la existencia o no de una regulación legal aplicable al caso [Fundamento de Derecho $5^{\circ}, \mathrm{B}$ d)].

3. En el caso concreto (transmisión de hepatitis) no hay fuerza mayor ni ausencia de antijuricidad de la lesión (Fundamento de Derecho $5^{\circ}, \mathrm{C}$ ).

La STS de 31 de mayo de 1999 muestra una preliminar tendencia a la prudencia en la aplicación del nuevo supuesto; muestra igualmente la inserción en la dogmática previa de responsabilidad objetiva. Ambas tendencias, sin duda, dulcifican la potencialidad de la nueva causa de exoneración de responsabilidad por riesgos del desarrollo. No obstante, dicho plan-

3 Sentencia que ha sido comentada por PéREZ GÁlvez en «Responsabilidad por acto sanitario y progreso de la "ciencia" o de la "técnica" ", Revista Española de Derecho Administrativo, ${ }^{\circ}$ 104, octubre-diciembre, 1999, pp. 657-673. 
teamiento podrá rebelarse insuficiente cuando vuelva a plantearse sobre un supuesto al que ya sea de plena aplicación (por tener lugar bajo la aplicación y vigencia de la Ley 4/1999) y la Administración cumpla con la probatio diabolica de ese estado insatisfactorio de la ciencia y de la técnica.

De hecho, la STS de 25 noviembre 2000, RJ 2001\550, (Sala de lo Contencioso-Administrativo, Sección $6^{\text {a }}$, Ponente Peces Morate, utilizando como elemento interpretativo el artículo 141.1 (Fundamento de Derecho $2^{\circ}$ in fine), ha determinado una inversión jurisprudencial que ahora niega la responsabilidad patrimonial de las Administraciones Públicas por contagio de la hepatitis $C$ «inevitable» según el estado de la ciencia o de la técnica. A partir de 1999 ya no es posible encontrar sentencias que afirmen responsabilidad en estos supuestos. Al artículo 141.1, aun no siendo aplicable se le concede valor interpretativo [así, la STS de 14 julio 2001 (Sala de lo Contencioso-Administrativo, Sección $\left.6^{\mathrm{a}}\right)$, RJ $2001 \backslash 6693$ a f. de dcho. $5^{\circ}$ ]. Esta última operación se nos antoja contraria a los artículos 9, 24 y 106.2 CE. Esperemos que recursos de amparo puedan combatir esta errónea doctrina.

El tiempo transcurrido permite realizar un recorrido por el análisis doctrinal y jurisprudencial de la cláusula de exoneración de responsabilidad expuesta. Buena parte de la doctrina administrativista y el propio Consejo de Estado ${ }^{4}$ la han saludado como una previsión razonable. Sin embargo, algunas voces se han mostrado contrarias a esta modificación de nuestro régimen de responsabilidad aportando una diversidad de argumentos que deben incitar a una profunda reflexión.

\section{A) TESIS: LA NORMA ES CONSTITUCIONAL}

Vamos a pasar revista a las posiciones más significativas mantenidas en torno al artículo 141.1 de la Ley 30/1992 que sostienen su constitucionalidad. Vaya por delante nuestro respeto absoluto por todas estas opiniones y por quienes las sustentan. Los debates son en este sentido enriquecedores y permiten el avance de la ciencia jurídica. El debate, precisamente, está teniendo este efecto: la ciencia jurídica sobre responsabilidad se ha puesto en tensión y de ello sólo pueden salir elementos positivos.

\section{La nueva previsión se inserta en la antijuricidad (GARCÍA DE ENTERRÍA, FERNÁNDEZ RODRÍGUEZ, MARTÍN REBOLLO, LÓPEZ MENUDO)}

Expongamos estas posiciones. Sostienen GARCÍA DE ENTERRÍA y FERNÁNDEZ RODRÍGUEZ sobre la reforma del artículo 141 lo siguien-

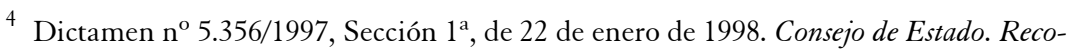
pilación de la Doctrina Legal 1998, p. 98. 
DA-2003, núms. 265-266. JESÚS JORDANO FRAGA. Ciencia, Tecnología, medio ambiente y respons...

te: «Es ésta una simple aclaración, no una modificación, de la cláusula general de responsabilidad y del juego que en el sistema que dicha cláusula establece corresponde a la idea de la antijuricidad del daño, que no puede predicarse, naturalmente, de aquéllos cuyo origen se desconoce o son inatajables de acuerdo con el estado de los conocimientos en el momento en que se producen y deben por ello ser soportados, como ya notamos, por quienes aceptan voluntariamente los riesgos inherentes a la intervención de la que resultan ${ }^{5} »$.

MARTÍN REBOLLO, la voz más autorizada en materia de responsabilidad de la Administración, no cree que existan motivos bastantes para la crítica por nosotros realizada y cree que el inciso final del artículo 141.1 obedece seguramente a una reacción frente a ciertas condenas de responsabilidad administrativa por la transmisión del VIH en transfusiones de sangre realizadas en hospitales públicos antes de la implantación de los controles de plasma, y antes incluso de que se conociera científicamente su propia existencia: entiende MARTÍN REBOLLO «el inciso perfila el concepto mismo de lesión, definiendo la Ley un supuesto en que sí hay un deber jurídico de soportar el daño, aunque plantea el problema -apasionantede la prueba y del ámbito de lo que de lo que haya de entenderse por el «estado de los conocimientos de la ciencia» ${ }^{6}$. LÓPEZ MENUDO también cree que el precepto se inserta en la antijuricidad explicando que éste era el sentido inicial de la reforma alterado en su tramitación como consecuencia del Dictamen del Consejo de Estado de 22 de enero de 19987. LÓPEZ MENUDO considera el precepto -por su ubicación en el art. 141- inserto en la antijuricidad: «se trata, pues, de la especificación de una causa de exoneración o, dicho de otro modo, de la delimitación hecha desde la propia Ley reguladora del instituto de la responsabilidad (como lo pudiera haber hecho cualquier otra) del campo de lo antijurídico para una suerte de daños. La nueva ley surge así para delimitar un supuesto de antijuricidad de confines harto discutidos en sede judicial y que han supuesto para los ciudadanos en no poco casos una injustificable desigualdad de trato» ${ }^{8}$. En su opinión, el ar-

${ }^{5}$ Curso de Derecho administrativo, Tomo II, $7^{\text {a }}$ edición, Civitas, Madrid 2000, p. 378.

6 «Ayer y hoy de la responsabilidad patrimonial de la Administración: un balance y tres reflexiones», RAP n ${ }^{\circ}$ 150, septiembre-diciembre 1999, p. 343.

7 «Responsabilidad administrativa y exclusión de los riesgos del progreso. Un paso adelante en la definición del Sistema», R.A.A.P $\mathrm{n}^{\circ}$ 36, octubre-noviembre-diciembre 1999, pp. 20-21. Explicando el temor a la inserción en la fuerza mayor por ser concepto constitucionalizado de los ponentes de la propuesta de reforma de la Ley 30/1992 (Jornadas de Estudio sobre la Reforma de la Ley 30/1992, B.O.E., serie Administración General, Madrid 1997, pp. 52-52).

8 «Responsabilidad administrativa y exclusión de los riesgos del progreso. Un paso adelante en la definición del Sistema», cit., p. 23. 
DA-2003, núms. 265-266. JESÚS JORDANO FRAGA. Ciencia, Tecnología, medio ambiente y respons...

tículo 106.2 CE no impone al legislador que el carácter de la responsabilidad de la Administración ha de ser objetivo en todo caso, «pues no hay que olvidar que la garantía es de configuración legal» ${ }^{9}$.

\section{La nueva previsión especificación de la fuerza mayor está en manos del legislador no conculcando la Constitución el artículo 141.1 de la Ley 30/1992}

Una pléyade de destacados autores ha considerado correcta la nueva cláusula de exoneración. Así, GONZÁLEZ PÉREZ y GONZÁLEZ NAVARRO, quienes mantienen, lejos de cualquier consideración crítica, que «con esta modificación de la regulación de la fuerza mayor, adquiere un papel relevante el estado de los conocimientos de la ciencia o de la técnica en el momento de la producción de los daños. La imposibilidad de prever o de evitar la producción del daño -que definen la fuerza mayor según la jurisprudencia- ha de referirse al estado de los conocimientos en el momento de producirse el daño» ${ }^{10}$ También GARCÍA ÁLVAREZ cree que la ampliación del concepto de fuerza mayor operada por el artículo 141.1 de la Ley 30/1992 no vulnera el artículo 106 CE porque la fuerza mayor en él recogido no garantiza una inmutabilidad del concepto. Rechaza que la garantía institucional cubra conceptos como la fuerza mayor. Por alusiones, diremos que el argumento decisivo invocado por nosotros en ningún momento es la garantía institucional sino la naturaleza de las cosas y el sistema objetivo de responsabilidad que creemos consagrado en el $106 \mathrm{CE}^{11}$. Probablemente la garantía institucional no cubre conceptos como la fuerza mayor, pero eso no significa que el legislador no tenga límites. Elevando el ejemplo al absurdo, la mayoría de edad no se puede fijar por el legislador en 18 años lunares por mucho que la Constitución no delimite expresamente el concepto años. Nosotros no reputamos inconstitucional el artículo 141.1 por violación de garantías institucionales sino por conculcación frontal de los artículos 9 y 106.2 CE y la propia naturaleza de las cosas. Cree el autor, no obstante, que la exoneración de responsabilidad en supuestos de transmisión de un virus indetectable es admisible consti-

9 «Responsabilidad administrativa y exclusión de los riesgos del progreso. Un paso adelante en la definición del Sistema», cit., p. 15, nota $\mathrm{n}^{\circ} 3$.

${ }^{10}$ Comentarios a la Ley de Régimen Jurídico de las Administraciones Públicas y del Procedimiento Administrativo Común (Ley 30/1992, de 26 de noviembre), segunda edición, Civitas, Madrid 1999, p. 2878.

${ }^{11}$ Cfr. «La reforma del artículo 141,apartado 1 de la Ley 30/1992, de 26 de noviembre, o el inicio de la demolición del sistema de responsabilidad objetiva de las Administraciones Públicas», R.A.P. n 149, mayo-agosto 1999, p. 336. 
tucionalmente pues la víctima en estos supuestos es un usuario del servicio público creado y gestionado en interés preponderante de los usuarios del mismo. Pero «la solución debe de ser distinta cuando la víctima sea paciente de un tratamiento sanitario obligatorio como una vacunación o, en general, cuando no tenga la condición de usuario del servicio, sino de tercero porque se trate de un servicio dirigido a la colectividad de los ciudadanos o bien, simplemente, porque él no se beneficia del mismo como usuario o no se beneficia en mayor medida que otros sujetos de la comunidad nacional» ${ }^{12} 1314$.

12 «La responsabilidad extracontractual de la Administración y de su personal en el Derecho comparado», R.Ar.A.P. $\mathrm{n}^{\circ}$ 18, junio 2001, pp. 419-420.

13 De parecida forma GARCía GÓMEZ DE MERCADO entiende que «el concepto de fuerza mayor será el que acoja nuestro ordenamiento jurídico y puede variar» y que bien entendido no es disconforme con el concepto dominante de fuerza mayor: «No se trata tanto de que el suceso puede ser inevitable y no sólo imprevisible sino de que sea ajeno al círculo del responsable y cuando los conocimientos técnicos y científicos no permiten evitar la producción del daño nos encontramos con causas ajenas a dicho círculo» («La responsabilidad patrimonial tras la Ley 4/1999», Actualidad Administrativa n ${ }^{\circ} 32,6$ al 12 de septiembre de 1999, p. 900). En esta misma línea, entiende PÉREZ Monguió que el art. 141.1 de la Ley 30/1992 no supone ninguna novedad ya que ese supuesto gozaba de todos los requisitos necesarios para ser considerado fuerza mayor sin necesidad de ninguna precisión de tipo legal. Considera que con la reforma se consiguen tres logros: 1)la ruptura con la hegemonía doctrinal y jurisprudencial de que el elemento de la exterioridad es determinante en la configuración de la fuerza mayor; 2) la constatación del abuso que se estaba produciendo del sistema de responsabilidad patrimonial «siendo incluidos casos que realmente estaban bastantes alejados de su órbita de incidencia pero que por considerarlos «injustos» y al no existir otro medio de resarcirlos se canalizaron a través de esta vía, y 3) se establece la posibilidad de recibir una compensación acogiendo de forma expresa la distinción entre la responsabilidad patrimonial y la «responsabilidad del Estado social» («Fuerza mayor en la responsabilidad extracontractual de la Administración Pública», R.Ar.A.P. n ${ }^{\circ}$ 18, junio 2001, pp. 357-376). No podemos compartir esta posición. La ruptura de una línea mayoritaria no es intrínsecamente un avance, sobre todo si como consecuencia del mismo se limita la existencia de responsabilidad. Dudoso avance es el que permite restringir indemnizaciones. La valoración positiva de la cláusula que el autor realiza a la luz de SIDA, donde la mayoría de los supuestos se produjeron ya con funcionamiento anormal (hoy seguiría habiendo responsabilidad) es ciertamente discutible ¿Puede garantizar el autor que en el próximo riesgo del desarrollo vaya a suceder lo mismo? Tampoco compartimos la segunda parte de la argumentación pues el régimen de indemnizaciones por leyes ad hoc pasa al ámbito de la discrecionalidad, y es inefectivo en supuestos de daños aislados o dispersos. Rechazamos el análisis civilista de la fuerza mayor que el autor realiza pues confunde responsabilidad extracontractual y contractual, y dentro de la extracontractual el supuesto de responsabilidad objetiva donde tiene pleno sentido la distinción entre caso fortuito y fuerza mayor ( $C f r$. pp. 360-364). Por otro lado, hay cierta contradicción en afirmar que se ha superado una concepción mayoritaria y que esto es un avance y decir que ya estaba previsto, negando, al mismo tiempo, que exista el concepto arraigado. Evidentemente en el fondo -que es lo relevante- se comparte la necesidad de indemnización y lo que se discute es el mejor modo de instrumentarla. Pues bien, el modo elegido aleatorio, ad hoc y rígido, es insatisfactorio y, en nuestra opinión, a la luz del art. 106.2 CE, inconstitucional.

$14 \mathrm{Al}$ margen de estas dos posiciones (existencia de la obligación de soportar/fuerza mayor) se sitúa Mir PUIGPELAT quien considera que el nuevo inciso del art. 141.1 configura un supuesto de no imputación estimando la reforma plenamente justificada y negando que suponga convertir la responsabilidad de la Administración en una responsabilidad por culpa. El 
DA-2003, núms. 265-266. JESÚS JORDANO FRAGA. Ciencia, Tecnología, medio ambiente y respons...

\section{La nueva previsión salva su constitucionalidad por su último inciso: (MONTORO CHINER)}

De gran peso es la aportación realizada por MONTORO CHINER. En síntesis, sostiene que el primer inciso del artículo 141.1 podría no estar en armonía con lo que el TC llama «las ideas generalizadas y convicciones generalmente admitidas» entre juristas, jueces y especialistas acerca de la fuerza mayor, ya que la imagen de la fuerza mayor, o los conceptos que la perfilan podrían resultar irreconocibles según la definición formulada por el artículo 141.1 de la Ley 30/1992, o, al menos, causar cierta inseguridad o incertidumbre $^{15}$. Si bien la responsabilidad no goza de garantía institucional, en su opinión, sí se conecta con derechos fundamentales pues puede llegar a garantizar mediante la indemnización la pérdida de un derecho fundamental como el derecho a la vida (por analogía), lo que fuerza la extensión de la doctrina antes aludida. Para MONTORO CHINER, el precepto «posiblemente» salva su inconstitucionalidad por su último inciso «todo ello sin perjuicio de las prestaciones asistenciales o económicas que las leyes puedan establecer para estos casos, que «en el fondo, no es más que otra forma de matizar la imputación y reconocer la propia responsabilidad mediante leyes ad hoc que establezcan las compensaciones oportunas para cada uno de los daños o las circunstancias en que estos pudieran aparecer» ${ }^{16}$. Creo que la tesis de MONTORO CHINER, que es rigurosa, pulida e impactante, tiene un pequeño «pero»: ¿y qué ocurre si esas leyes ad hoc no llegan, por ejemplo, si los daños generados han sido minoritarios y dispersos o porque discrecionalmente el legislador no considera apropiado actuar ${ }^{17}$ ? Si lo que salva la constitucionalidad del precepto es la garantía realista de indemnizaciones, la cláusula elegida por el legislador es defectuosa. Suponiendo que esta

fundamento que maneja es la imputación objetiva («La reforma del sistema de responsabilidad patrimonial de las Administraciones Públicas operada por la Ley 4/1999, de 13 de enero, de modificación de la LRJPAC», Revista Jurídica de Catalunya, $\mathrm{n}^{\circ}$ 4, Any XCVIII, 1999, pp. 63-70; La responsabilidad patrimonial de la Administración sanitaria. Organización, imputación y causalidad, Civitas, Madrid 2000, pp. 278-284; La responsabilidad patrimonial de la Administración. Hacia un nuevo sistema, Civitas, Madrid 2002, pp. 49-59 ). La construcción nos parece tautológica: no hay responsabilidad porque no son imputables, «el daño pese a haber sido causado por la Administración, no le podrá ser imputado, porque no podrá ser considerado obra del servicio público». Lo cierto es que los daños son causados por el servicio público y lo que no existe es culpa pero sí responsabilidad conforme al art. 106.2 CE. Rectificamos al autor en dos apreciaciones que nos imputa erróneamente. Ni afirmamos que el sistema de Nueva Zelanda es un sistema de responsabilidad -ese añadido es suyo- ni hemos propuesto la limitación de indemnizaciones -sólo decimos que es una opción que presenta menos obstáculos de constitucionalidad-.

15 Montoro Chiner \& Hill Prados, Responsabilidad patrimonial de la Administración y contrato de seguro, Atelier administrativo, Barcelona 2002, pp. 22-25.

16 Op. cit., p. 24.

17 Y esto no es política-jurídica ficción. Respecto de los contagiados por hepatitis sólo Cataluña ha establecido ciertas ayudas sociales. Vid. COMINGES CÁCERES, «Análisis jurisprudencial de la responsabilidad administrativa por contagio de hepatitis C», R.A.P. $\mathrm{n}^{\circ}$ 155, mayo-agosto 2001, p. 221. 
DA-2003, núms. 265-266. JESÚS JORDANO FRAGA. Ciencia, Tecnología, medio ambiente y respons...

cláusula sea constitucional, en caso de falta de ejercicio de esa abstracta y eventual potestad legislativa ad hoc habría inconstitucionalidad por omisión. Me parece que para que, desde este punto de vista, se pudiera salvar la constitucionalidad el artículo 141.1 in fine debiera haber remitido o reenviado a un sistema de solidaridad cierto, estable y concreto. Ese discrecional e incierto reenvío es, desde esta perspectiva, realmente insatisfactorio.

\section{B) ANTÍTESIS}

1. La exclusión de responsabilidad en riesgos del desarrollo es indeseable (ESTEVE PARDO, GOLDENBERG)

ESTEVE PARDO, pionero en la crítica, ha sostenido que la aceptación de la impunidad de los riesgos del progreso o del desarrollo, además de carecer en la sociedad tecnificada de justificación actual, convierten a la postre a las personas, a la sociedad y al medio ambiente en laboratorios experimentales ${ }^{18}$; GOLDENBERG cree que la afirmación de responsabilidad en estos supuestos alentaría la función preventiva, la investigación y la puesta al día de los conocimientos enfatizándose que no se trata de un caso fortuito ajeno a la actividad empresarial ${ }^{19}$. Dicho de otro modo, esta cláusula de exoneración no pondera adecuadamente los bienes jurídicos en conflicto. En teoría, la exoneración por los riesgos del desarrollo protege o pretende proteger la innovación que suponen los nuevos productos o técnicas. La obtención de una exoneración de responsabilidad puede ser vista como un incentivo a la innovación (pero no como apunta GOLDENBERG a la innovación e investigación preventiva). Frente a este valor se sitúa la sociedad en su conjunto y su protección frente a futuros daños. La cuestión, como acertadamente señala ESTEVE PARDO, es para qué se protege la innovación.

\section{La exención de responsabilidad operada por el artículo 141.1 de la Ley 30/1992 como norma inconstitucional o contraria al Derecho de la Unión Europea (LEGUINA VILLA, SALVADOR CODERCH, MARÍN LÓPEZ)}

De forma contundente LEGUINA VILLA considera que la «menos afortunada de todas las reformas del sistema de responsabilidad» es la

18 En su impresionante libro Técnica, Riesgo y Derecho. (Tratamiento del riesgo tecnológico en el Derecho ambiental), Ariel Derecho, Ed. Ariel S.A., Barcelona 1999, pp. 209-215.

19 «Riesgos del desarrollo y daño ambiental» en VV.AA., Responsabilidad por daños en el tercer milenio, Homenaje al Profesor Doctor Atilio Aníbal Alterini (Alberto José BuEREs y Aída Kemelmajer de Carlucci, Dir.), Abeledo-Perrot, Buenos Aires 1997, p. 344. 
introducida en el apartado 1 del artículo 141. Cree que la Exposición de Motivos de la Ley «silencia las verdaderas razones que amparan tan importante inmunidad patrimonial, limitándose a encubrir aquéllas bajo el manto protector de la fuerza mayor», siendo en su opinión «claro» que «los daños a los que el precepto se refiere no configuran en rigor supuestos de fuerza mayor» derivados de fenómenos imprevisibles, irresistibles y, sobre todo, extraños a la organización y actuación administrativa ${ }^{20} »$. De forma que los daños que el artículo 141.1 pretende excluir de cobertura indemnizatoria se producen por el contrario, en el ámbito de la organización administrativa: «son daños derivados del funcionamiento normal de los servicios públicos, imputables a caso fortuito y cubiertos, por tanto, en principio, por la cláusula general de responsabilidad por riesgo». Cree LEGUINA VILLA que con la nueva excepción legal «se pretende poner límites a un sistema de responsabilidad objetiva por daños fortuitos, cuyo potencial alcance algunos juzgan desmesurado e insoportable para las arcas públicas, a mi modo de ver con fundamento más imaginario que real». Considera que el texto utilizado para apartar de la cobertura indemnizatoria de los particulares «algunos» riesgos administrativos (los que la ciencia no permite prever o la técnica evitar) podría reorientar el entero sistema de responsabilidad administrativa hacia criterios de culpabilidad, en una dirección regresiva, por tanto, y de difícil conciliación con lo dispuesto en el artículo 106.2 de la Constitución y en el artículo 139 de la propia LRJ-PAC 21.

Desde la doctrina civilista hay críticas implacables como la de SALVADOR CODERCH, que transcribimos parcialmente por su interés: dice

20 En este sentido GarCía LlOvET coincide en que el nuevo art. 141.1 introduce una nueva dimensión de imprevisibilidad e inevitabilidad que va mucho más allá de los supuestos de fuerza mayor al no conectarse a un elemento extraño al funcionamiento del servicio público [«El régimen de responsabilidad patrimonial de las Administraciones Públicas tras la reforma de la Ley 30/1992. Un problema resuelto, un nuevo problema» en VV.AA., $L a$ responsabilidad patrimonial de las Administraciones Públicas, Bello JaneIro, Domingo (Dir.),Colección Xornadas e seminarios n ${ }^{\circ}$ 22, EGAP, Santiago de Compostela, 1999, p. 331]. PELAYO PARDOS cree potencialmente contrario al art. 106.2 CE el nuevo apartado introducido porque modifica por ley un concepto constitucional y doctrinal de fuerza mayor para restringirlo ( Sida, hepatitis y artículo 37 de la Ley 4/1999 de modificación de la Ley 30/1992». La teoría de los riesgos del desarrollo, D 68, La Ley 1999, tomo 2, p. 1711).

21

LEguina VILLA, «La reforma de la Ley de Procedimiento», Justicia Administrativa, $\mathrm{n}^{\circ}$ 7, abril 2000, pp. 13-14. La última idea expresada la explica del siguiente modo: «hasta ahora el caso fortuito imputable a la Administración cubría tanto los hechos dañosos imprevisibles, según el estado de los conocimientos científicos, como los hechos dañosos previsibles pero inevitables, según el estado de los conocimientos técnicos. Pero si a partir de ahora la Administración no responde ni de unos ni de otros, como así se afirma literalmente en el nuevo texto del art. 141.1, sólo quedarían a su cargo los hechos dañosos previsibles y evitables pero no previstos ni evitados, es decir, respondería solo de los daños culpables o por funcionamiento anormal $» . .$. «Difícil tarea les espera a los jueces en el trazado de la nueva frontera (si hay alguna) que separe riesgos indemnizables del art. 139 de los riesgos no indemnizables del art. 141.1». 
DA-2003, núms. 265-266. JESÚS JORDANO FRAGA. Ciencia, Tecnología, medio ambiente y respons...

el autor refiriéndose al precepto que comentamos: «Así y en primer lugar, parece olvidarse que los poderes públicos deben organizar» y tutelar la salud pública a través de medidas preventivas» (art. $43.2 \mathrm{CE}$ ) y que una medida preventiva de primer orden es una regulación de responsabilidad civil que exija, caso de producirse el accidente, la reparación integral de los daños. Parece olvidarse también que la regla del nuevo artículo 141 prescinde incluso de responsabilidad por negligencia -culpa in vigilando-, pues, al fijar como elemento relevante el de la producción del daño ni siquiera se incentiva a los poderes públicos a prestar atención al desarrollo de los conocimientos científicos y tecnológicos que han tenido lugar entre el momento de la comercialización del producto y el-acaso muy posterior- de la producción del daño. Y parece olvidarse, por último, que una cosa es el daño que no pudo preverse, pero otra muy distinta el que no pudo evitarse: excluir de responsabilidad por riesgos del desarrollo en daños previsibles, pero inevitables quiere decir, por ejemplo, que si sabemos que tal vacuna genera reacciones graves en uno por un millón de la población vacunada, pero no sabemos cómo evitar el daño, la vacuna podrá suministrarse -acaso obligatoriamente- pero el Estado cumplirá con auxiliar a las víctimas, pues la ley no le obliga a indemnizarlas» ${ }^{22}$.

También MARÍN LÓPEZ critica la nueva regulación. Sostiene MARÍN LÓPEZ lo siguiente: 1) el derecho de los particulares a ser indemnizados por los daños causados por la Administración lo es «en los términos establecidos por la Ley», lo que significa reconocer al legislador un amplio margen de configuración de este derecho de los particulares, dentro del cual tendrá perfecta cabida la decisión plasmada en el nuevo artículo 141.1. El contenido de los conceptos «lesión» $\mathrm{o}$ «fuerza mayor» es el previsto en cada caso y momento por el legislador, de manera que éste puede disponer a través de una norma con rango de ley que un determinado daño a los particulares no constituye «lesión» resarcible por la Administración o «fuerza mayor» que rompe el nexo de causalidad exigible ${ }^{23}$;2) la «estratégica» reconducción del nuevo inciso

${ }^{22}$ Brujos y aprendices. Los riesgos del desarrollo en la responsabilidad del producto, cit., pp. $15-16$.

23 Daños por productos: estado de la cuestión, Tecnos, Madrid 2001, pp. 264-265. El autor se plantea en definitiva a la vista de nuestra tesis la existencia de límites constitucionales «núcleos duros» en relación con la fuerza mayor y con el concepto de lesión indemnizable, si bien no cree que en el supuesto se hayan vulnerado -en lo que se refiere a la fuerza mayor-, por descartar que nuestra Constitución reconozca un sistema de responsabilidad objetiva y que la doctrina y jurisprudencia sobre la fuerza mayor definan necesariamente esos núcleos duros. ¿Cómo conciliar esto con la previa libertad que ostenta presuntamente el legislador?, ¿y cuáles serían los núcleos duros de la fuerza mayor? Creemos igualmente que incurre en una patente contradicción al afirmar que el art. 106.2 CE no reconoce un sistema objetivo de responsabilidad y lo contrario: $c f r$. pp. 267 y 280 . Y esta contradicción no es intrascendente sobre lo que se mantiene. Tampoco creemos que rebata nuestra posición «fácilmente». Para ello 
del artículo 141.1 al ámbito de antijuricidad, hábilmente trabada por los autores del borrador, no les libera de un eventual reproche de inconstitucionalidad. Y ello porque el concepto de «lesión» tiene un contenido constitucional propio que no puede ser violentado por el legislador al establecer los términos concretos en que responde la Administración por los daños causados ${ }^{24}$. En concreto, siguiendo en buena medida a SALVADOR CODERCH, critica que se haya seleccionado el momento de producción de los daños y no el de la puesta en circulación de productos como en sede sectorial de responsabilidad del fabricante de productos ${ }^{25}$; destacadamente denuncia que no se hayan respetado los requisitos formales de comunicación a la Comisión del artículo 15.2 de la Directiva 85/374,y sobre todo, el empleo de la cláusula disyuntiva imprevisibles o inevitables que deja fuera de la responsabilidad supuestos antes cubiertos ${ }^{26}$.

\section{Nuestra posición ${ }^{27}$}

Nosotros hemos sostenido que esta previsión es inconstitucional ${ }^{28}$. Nuestra tesis es la siguiente:

a) La innovación, discutible como todo en Derecho, es restrictiva en cuanto al anterior estado de la cuestión: piénsese que supuestos que han sido considerados dentro del ámbito de la responsabilidad quedarán fuera a partir de ahora (señaladamente,

debería justificar que la exterioridad no es núcleo duro y que el 106.2 CE no reconoce un sistema objetivo de responsabilidad (pues el art. 106.2 CE sólo excluye la fuerza mayor como causa exoneradora, pero no el caso fortuito).

24 Daños por productos: estado de la cuestión, cit., p. 271 y ss.

${ }^{25}$ Cfr. Daños por productos: estado de la cuestión, cit., p. 280.

${ }^{26}$ Cfr. Daños por productos: estado de la cuestión, cit., pp. 281-282. Sigue esta tendencia la STS de 21 junio 2001, Ar. 2001\7425, (Sala de lo Contencioso-Administrativo, Sección 6 ${ }^{a}$ ), Ponente Álvarez-Cienfuegos Suárez, f. de dcho. $4^{\circ}$ que, a nuestro juicio, confirma los temores expresados por SALVADOR CODERCH y MARÍN LÓPEZ al poner el acento en la inevitabilidad del contagio de la entonces ya conocida como hepatitis no A no B. Véase, al respecto, el impresionante voto particular de González Navarro a la STS de 19 junio 2001 (Sala de lo Contencioso-Administrativo, Sección $6^{a}$ ), RJ 2001\10059, que cuestiona las bases fácticas de la negación de responsabilidad en estos supuestos y denosta la falta de prueba por parte del INSALUD.

27 Esta posición está expuesta en «La reforma del artículo 141, 1, apartado 1, de la Ley 30/1992, de 26 de noviembre, o el inicio de la demolición del sistema de responsabilidad objetiva de las Administraciones Públicas», R.A.P. n ${ }^{\circ} 149$ mayo-agosto 1999, pp. 321-336 y en La reparación de los daños catastróficos (Catástrofes Naturales, Administración y Derecho público: responsabilidad, seguro y solidaridad), Marcial Pons 2000.

28 Obviamente será, en su caso, el máximo intérprete de la Constitución, esto es, el TC quien deberá declarar o no dicha inconstitucionalidad. 
DA-2003, núms. 265-266. JESÚS JORDANO FRAGA. Ciencia, Tecnología, medio ambiente y respons...

los contagios del SIDA antes de que la ciencia conociera las causas de la enfermedad ${ }^{29}$ como consecuencia de transfusiones realizadas en el servicio público de salud o tratamientos con productos hemoderivados). Antes de la Ley 4/1999, en la doctrina se ha discutido si estos supuestos de riesgos imprevisibles e inevitables (en concreto con el problema del SIDA) eran constitutivos de fuerza mayor o caso fortuito. MUGA MUNOZ cree que el contagio de SIDA en una transfusión sería un supuesto de fuerza mayor ${ }^{30}$. En contra, creemos que con razón, se ha pronunciado BELADIEZ ROJO ${ }^{31}$.

- Creemos que ha ido mas allá de lo constitucionalmente permitido estableciendo una cláusula exclusora de pretendidos supuestos matizados de fuerza mayor en realidad bajo la cobertura de los artículos 9 y 106. 2 CE. Faltaría en este nuevo supuesto identificado de «fuerza mayor» en todo caso la nota de la exterioridad como elemento fundamental de la distinción: puede haber eventos imprevisibles e inevitables en los que se afirme la responsabilidad por no existir fuerza mayor pese a la ausencia total de culpa: Y es evidente que esto es desconocido por el legislador al tratar de identificar un nuevo supuesto de fuerza mayor donde sólo hay todo lo más un caso fortuito por faltar la nota de la exterioridad ${ }^{32}$. Los riesgos del

${ }^{29}$ La jurisprudencia penal social y contencioso-administrativa habían afirmado esta responsabilidad (véase el conjunto de sentencias recopiladas por MUGA MUÑOZ en su estudio «La responsabilidad patrimonial de la Administración Pública por el contagio del sida», R.A.P. $\mathrm{n}^{\circ}$ 136, enero-abril, 1995, pp. 290-294). Sintetizando brillantemente la ultimísima jurisprudencia y doctrina al efecto, véanse MARÍN LÓPEZ, Daños por productos: estado de la cuestión, cit., pp. 244-254 y COMINGES CÁCERES, «Análisis jurisprudencial de la responsabilidad administrativa por contagio de hepatitis C», R.A.P. $\mathrm{n}^{\circ} 155$, mayo-agosto 2001, pp. 193-222. Como hemos señalado, desde la Sentencia Tribunal Supremo (Sala de lo Contencioso-Administrativo, Sección $6^{\text {a }}$ ), de 25 noviembre 2000, RJ 2001\550, Ponente Peces Morate, se rechaza la responsabilidad en estos supuestos ( $\mathrm{VIH}$, hepatitis $\mathrm{C}$ ) contagiada por transfusiones en el momento en que el virus es indetectable. Siguen esta tendencia las SSTS (Sala de lo Contencioso-Administrativo, Sección 6a), de 21 junio 2001, Ar. $2001 \backslash 7425$ Ponente Álvarez-Cienfuegos Suárez; 19 junio 2001, RJ 2001\10059, Ponente Álvarez-Cienfuegos Suárez; de 14 noviembre 2001, RJ 2002\480, Ponente Álvarez-Cienfuegos Suárez. La última sentencia post art. 141 en la que se duda de la responsabilidad patrimonial en estos supuestos es la STS de 19 junio 2001, RJ 2001\10059(Sala de lo Contencioso-Administrativo, Sección $6^{\mathrm{a}}$ ), sobre la cual formula un extenso y certero -en lo fáctico- voto particular González Navarro.

30 «La responsabilidad patrimonial de la Administración Pública por el contagio del sida», cit., pp. 289- 290.

31 Responsabilidad e imputación de daños por el funcionamiento de los servicios públicos, cit., p. 127, nota $\mathrm{n}^{\circ} 33$.

32 Esto que afirmamos se ve con mayor claridad a la luz de la jurisprudencia (STS de 25 de octubre de 1996, Ar. 7124, Sala 3 ${ }^{\text {a }}$, Sección $6^{\text {a }}$, Ponente Xiol Ríos; STS de 28 de enero de 1991, Ar. 661, Sala 3a, Sección 4a Ponente Rouanet Moscardó, f. de dcho. no 2). Lo definitorio para apreciar la concurrencia de caso fortuito (y por tanto, la existencia de responsabilidad patrimonial) es que el evento se produzca en la esfera de actividad o riesgo 
desarrollo no son fuerza mayor por faltar el requisito de la ajenidad o exterioridad ${ }^{33}$.

A la luz de estos datos parece evidente que el supuesto identificado por el legislador no es «fuerza mayor». Salva el legislador la restricción remitiendo a las prestaciones que puedan establecerse discrecionalmente: el resultado es obvio. De existir derecho a la reparación integral se pasa a la posibilidad discrecional del establecimiento de prestaciones asistenciales o económicas ${ }^{34}$.

- En síntesis, creemos que la nueva regulación contradice de modo frontal el artículo 106. 2 CE. Su base filosófica puede ser aceptable en parámetros civilistas pero no en los del Derecho administrativo nacional. La exclusión única de la fuerza mayor consagra constitucionalmente un sistema de responsabilidad objetiva y esa decisión constitucional no puede ser desvirtuada por el legislador. El legislador frente a la instauración posible-no necesariamente deseable - de un sistema limitativo pero respetuoso con los fundamentos constitucionalizados, ha operado en esa dirección por la vía indirecta de la identificación de nuevos supuestos de «fuerza mayor». Al hacerlo en contra de la naturaleza de las cosas se violan no sólo las bases conceptuales de la fuerza mayor sino el propio artículo $106 \mathrm{CE}$, iniciando la demolición

administrativo. Otro buen ejemplo de ello es la STS de 12 de marzo de 1984, Ar. 2508, Sala 4 a , Ponente Marín Ruiz y STS de 12-7-1985, Ar. 4209, Sala 4a, Ponente Díaz Eimil, cuyos considerandos $2^{\circ}$ y $4^{\circ}$ recogen esta doctrina.

33 Por todos, GUÉGAN, «L'apport du principe de précaution au droit de la responsabilité civile», Revue Juridique de l'environnement $\mathrm{n}^{\circ} 2,2000$, p. 174, nota 138. También la jurisprudencia francesa ha rechazado que sea fuerza mayor, incluso si se trata de un vicio oculto de producto teniendo en cuenta los medios de la época ( RADÉ, une nouvelle étique de la responsabilité» en VV.AA., Le principe de précaution, numéro especial 2000 de la Revue Juridique de l'environnement, p. 86).

34 El fundamento de ello es la imputación objetiva; o, si se prefiere, la idea de la necesidad de superación de un sistema de responsabilidad objetiva por considerarse intolerable la responsabilidad sin culpa o sin funcionamiento anormal. La duda planteable es si este esquema es compatible con el sistema de responsabilidad objetiva constitucionalizado (art. 106 CE). Si el objetivo es la limitación del quantum de responsabilidad como amenaza a la estabilidad presupuestaria o a la Hacienda Pública caben otras soluciones tal vez menos populares pero más compatibles con el sistema constitucionalizado. Como hemos apuntado, cabría al amparo del art. 106.2 CE limitar las posibles indemnizaciones o incluso establecer por ley de forma previa su cuantía en el ámbito de la Sanidad (obviamente, sin reducir las posibles indemnizaciones a cuantías irrisorias). Creo que resulta necesaria una aclaración: nosotros no defendemos que se limite la responsabilidad patrimonial cuantitativamente en determinados ámbitos. Por eso decimos en cursiva que esto no es necesariamente deseable. Lo único que sostenemos es que el juicio de constitucionalidad de esa forma de operar hubiera comportado menos problemas -hay autores que consideran incluso esta opción inconstitucional-al ser la responsabilidad objetiva constitucionalizada «en los términos que las leyes establezcan». 
DA-2003, núms. 265-266. JESÚS JORDANO FRAGA. Ciencia, Tecnología, medio ambiente y respons...

del sistema objetivo de responsabilidad de las Administraciones Públicas constitucionalizado.

El potencial explosivo de la exoneración por riesgos del desarrollo no tiene límites: no se refiere sólo al campo sanitario: hoy la técnica genera riesgos del desarrollo en múltiples ámbitos: el energético, la ingeniería genética, incluso en grandes obras públicas donde sean usados presuntos avances en técnicas constructivas o en materiales. Se pueden generar daños catastróficos de grandes dimensiones donde aparezca la Administración bien en primera línea actuando o gestionando directamente, concausalmente autorizando, otorgando concesiones, o regulando ${ }^{35}$. Por eso, de admitirse su constitucionalidad (cosa que nosotros no creemos posible), la inclusión de una cláusula general de exoneración con fundamento en los riesgos del desarrollo quizá hubiera debido ser suavizada, al menos, eliminado de su ámbito de aplicación los daños corporales (físicos o psicofísicos).

- Pero esta posibilidad en caso de daños dispersos e individualizados fácticamente puede desaparecer. El proceso legislativo es complejo y no es fácil promulgar leyes ad hoc para cada supuesto de daños que sean consecuencia de riesgos del desarrollo. Esta dificultad puede abocar al desamparo de supuestos sangrantes en pleno siglo XXI. Además, la diversidad institucional tiene o puede tener indeseables efectos tributarios. Las indemnizaciones ex título responsabilidad están exentas frente al albur de dicha consecuencia en las «indemnizaciones» solidarias $^{36}$. La cláusula adolece de una doble inseguridad jurídica. No sólo en la eventual reparación solidaria ad hoc sino en los parámetros de la exclusión. ¿Cuál es el estado de la ciencia o de la técnica? ¿el conocido/accesible en España, la UE o el mundial? ${ }^{37}$, ¿̇se im-

35 La Reparación de los Daños Catastróficos, Marcial Pons Madrid 2000, p. 54. Véase también DESDENTADO DAROCA, «Reflexiones sobre el artículo 141.1 de la Ley 30/1992 a la luz del análisis económico del Derecho», R.E.D.A. no 108, octubre-diciembre 2000, p. 560. Hemos de decir que del rastreo por nosotros realizado terminado el 1 de agosto de 2002, no se observa por el momento la aplicación de la nueva causa de exoneración fuera del ámbito sanitario.

36 Pascual GarCía, Régimen jurídico de las subvenciones públicas, Colección Estudios Jurídicos 6, tercera edición, Ministerio de la Presidencia, B.O.E., Madrid 1999, pp. 412-413. Cfr. art. 7 d) de la Ley 40/1998, de 9 de diciembre, del Impuesto sobre la Renta de las Personas Físicas.

37 En parecidos términos, señalando la indefinición, MARTíN REBOLLO, «Ayer y hoy de la responsabilidad patrimonial de la Administración: un balance y tres reflexiones», cit., p. 343, nota $\mathrm{n}^{\circ}$ 44. EsTEVE PARDO da cuenta de cómo la expresión estado de la ciencia y de la técnica (Stand von wissenschaft und Technik) es utilizada en la legislación alemana para exigir un estándar técnico -normalmente de seguridad-, superior al ordinario siendo la fórmula empleada por la legislación de energía nuclear («La adaptación de las licencias a la mejor tecnología disponible», Revista de Administración Pública, no 149, mayo-agosto 1999, p. 52, nota 17). 
pondrá el parámetro BAT (mejor tecnología disponible a coste económicamente racional? Qué decir del estado dinámico de la ciencia o de la técnica y del mismo carácter dinámico de ciertos daños. Si el precepto no es declarado inconstitucional que es lo que en buena lógica debe ocurrir, la interpretación restrictiva debe excluir a radice este tipo de interpretaciones ampliadoras de la cláusula de exoneración ${ }^{38}$.

De lege data, la exoneración de responsabilidad por riesgos del desarrollo en el ámbito del Derecho privado no es además una regla inmutable. La Directiva 374/85, de 25 de julio, en materia de responsabilidad civil por los daños ocasionados por productos defectuosos deja en este aspecto libertad de decisión a los Estados miembros, pero el artículo 6.1 e) de la Ley 22/1994, de 6 de junio, excluye la exoneración por riesgos del desarrollo cuando los daños son producidos por el carácter defectuoso de medicamentos o productos alimenticios destinados al consumo humano $^{39}$. Y existe una sólida doctrina jurisprudencial de nuestro TC sobre la inconstitucionalidad de la divergencia de régimen jurídico entre sujetos públicos y privados cuando no existe una razón que justifique el privilegio. Por ejemplo, STC 15 de septiembre de 1997 (Sala 2a), recurso de amparo núm. 1130/1992 donde se estima violado el artículo 14 CE (la igualdad ante la ley), por las diferencias de trato legislativo, entre la Hacienda pública y los particulares en relación con el pago de intereses de demora en ejecución de sentencias (computo ex art. 45 LGP en relación con el antiguo art. 921 LECiv) cuando no hay una razón constitucionalmente relevante para justificar un distinto trato en el devengo del interés de demora, según la posición que ocupe la Hacienda Pública y sólo por ella ${ }^{40}$. Pues bien, la Administración puede fabricar y de hecho cuando ello sucede estamos ante un contrato considerado como de suministro ${ }^{41}$.

38 Proponiendo una interpretación restrictiva del precepto en consonancia con las conclusiones del Abogado General Sr. Tesauro en relación con la STJCEE de 29 de mayo de 1997, véase LÓPEZ MENUDO, «Responsabilidad Administrativa y Exclusión de los riesgos del progreso. Un paso adelante en la definición del Sistema», R.A.A.P $\mathrm{n}^{\circ} 36$, octubre-noviembrediciembre 1999, pp. 43-44.

39 De la Vega GARCía, Responsabilidad civil derivada del producto defectuoso. Un estudio de la Ley 22/1994 en el sistema de responsabilidad civil, Estudios de Derecho Mercantil, Civitas, Madrid 1998, pp. 98-99, calificando esta causa de exoneración como peligrosa; DíEZ-PICAZO y PONCE de LeÓn, Derecho de Daños, Civitas, Madrid, 1999, pp. 154-155; Chadelat, «Risque de développement», Revue Générale du Droit des Assurances, 1998, n 3, pp. 453-459.

${ }^{40}$ Vaticinando la no inconstitucionalidad, pero considerando injustificada la divergencia véase MARÍN LÓPEZ, Daños por productos: estado de la cuestión, cit., pp. 285-285. También COMINGES CÁCERES cree que la nueva regulación introduce un privilegio o trato de favor hacia la Administración («Análisis jurisprudencial de la responsabilidad administrativa por contagio de hepatitis C», R.A.P. $\mathrm{n}^{\circ}$ 155, mayo-agosto 2001, p. 221).

41 Art. 172 c) del RDLeg 2/2000, de 16 de junio. 
DA-2003, núms. 265-266. JESÚS JORDANO FRAGA. Ciencia, Tecnología, medio ambiente y respons...

\section{C) Síntesis. Elementos para un debate}

La discusión transcrita muestra la existencia de un problema patente que es el propio sistema de responsabilidad de las Administraciones públicas. Es fácil detectar que hemos pasado de la alabanza de un sistema objetivo de responsabilidad a su cuestionamiento doctrinal más o menos velado. Creemos que con la exoneración por riesgos del desarrollo se ha comenzado ese cuestionamiento en nivel legislativo. Creo que LEGUINA VILLA y DíEZ-PICAZO ${ }^{42}$ tienen razón cuando señalan cómo una de las consecuencias de la reforma es la alteración del sistema objetivo al introducir la culpa como elemento determinante de imputación de la responsabilidad patrimonial de las Administraciones Públicas. La cuestión es si nuestro artículo 106.2 CE soporta esta modificación. Cuando al amparo de la nueva cláusula de exoneración se plantee un caso duro (por su impacto social, por el número de afectados) inevitablemente éste acabará ante el Tribunal Constitucional. Y aquí tendremos la verdadera síntesis.

No creemos que la exoneración de los riesgos del desarrollo pueda ser salvada desde la idea de que estaríamos ante daños que el ciudadano tenga la obligación de soportar ${ }^{43}$. Expliquemos esto: en el ámbito sanitario, desde luego, no existe un derecho al éxito de la operación o intervención del servicio sanitario por la propia configuración del servicio sanitario como una obligación de medios ${ }^{44}$. Como regla general,

42 Así, DíEZ-PICAZO Y PONCE de LEÓN cree que el precepto no alude a una fuerza mayor que excluya la causalidad, «sino que introduce factores que pertenecen al terreno de la culpabilidad"; y también afirma que «Nos encontramos, a partir de este momento con una responsabilidad que en líneas de principio continúa siendo objetiva, aunque se permiten causas de exoneración en atención a factores determinantes de exclusiones de culpabilidad, de modo que el sistema se sitúa en una zona de un cierto eclecticismo» (Derecho de Daños, Civitas, Madrid 1999, p. 62). Dicho de otro modo, la exoneración por riesgos del desarrollo altera un sistema de responsabilidad objetiva, introduciendo rasgos o elementos subjetivos en el sistema de responsabilidad.

43 Tampoco Rebollo PUig, quien piensa que la obligación de soportar es algo que fluye de todo el ordenamiento jurídico y fundamentalmente de los principios generales del Derecho (Jornadas de Estudio sobre la Reforma de la Ley 30/1992, B.O.E., serie Administración General, Madrid 1997, p. 47).

44 En este sentido PÉREZ-TENESSA, quien cree que el error en el diagnóstico prenatal puede ser causa de responsabilidad patrimonial de la Administración sanitaria, cuando no se hayan aplicado las técnicas adecuadas con arreglo a la lex artis ad hoc o incluso cuando por la defectuosa información se haya perdido la oportunidad de interrumpir legalmente el embarazo, siempre que se den los demás requisitos que exige la ley. Para apreciar esos requisitos debe tenerse en cuenta que el nacimiento per se no es un daño, que no existe en nuestro ordenamiento un derecho al aborto, que el derecho constitucional a la protección de la salud no garantiza el resultado, sino la adopción de medidas preventivas y las prestaciones y los servicios necesarios, y que no se puede declarar la responsabilidad con base a meras hipótesis ( «Sobre el diagnóstico prenatal como causa de responsabilidad», R.A.P. n $^{\circ}$ 154, enero-abril 2001, pp. 47-61). En parecidos términos, la Sentencia del Tribunal Supremo (Sala de lo Contencioso-Administrativo, Sección 6ª), de 22 diciembre 2001, RJ 2002\1817, Ponente Peces Morate. 
DA-2003, núms. 265-266. JESÚS JORDANO FRAGA. Ciencia, Tecnología, medio ambiente y respons...

en una intervención de riesgo, la Administración sólo será responsable si existe culpa o funcionamiento anormal. Cuando el ciudadano usa el servicio público sanitario debe soportar los riesgos de su utilización. Pero esto no cubre los daños colaterales externos al acto de intervención técnico (como un contagio de cualquier virus desconocido, etc.) y que no sean fuerza mayor -estos últimos supuestos de fuerza mayor estarían excluidos de responsabilidad con fundamentación diferente-. La Ley 4/1999 va más allá al exonerar por vicios ocultos técnicos. Colocarse voluntariamente ante un riesgo conlleva la obligación de soportar (por todas, STS 2 de abril de 1994, Ar, 2722). Pero el particular, en el ejemplo propuesto, se coloca ante el riesgo propio de la intervención no ante riesgos exógenos a la intervención. Operarse no conlleva la obligación de soportar todos los riesgos (piénsese, elevando una vez más el ejemplo al absurdo, en el desgraciado caso del contagio de hepatitis por personal médico toxicómano). Precisamente por esto nuestro sistema era de responsabilidad objetiva. Hoy, tras la Ley 4/1999, sólo se responderá por culpa o funcionamiento anormal. Otro de los criterios tradicionalmente manejados para no estimar presente la obligación de soportar es la anormalidad del daño con ruptura del principio de igualdad ante las cargas públicas ${ }^{45}$. Los dañados por los riesgos del desarrollo sufren singularmente un daño potencialmente anormal rompiéndose el principio de igualdad antes los riesgos del desarrollo. Esto es patente, si atendemos al carácter dinámico de los mismos: pasaría a existir responsabilidad en el momento del avance técnico (la posibilidad técnica de detección del virus, en el ejemplo de las transfusiones) generándose una diacrónica diferencia de trato. Ciudadanos reparados integralmente frente a ciudadanos abandonados a la «generosidad» del legislador $\mathrm{ad}$ $h o c$. La única diferencia real seleccionada es la existencia de culpa (una presunta fuerza mayor según el legislador o de la obligación de soportar según los intérpretes del art. 141.1). La ley también puede determinar la obligación de soportar. Esto no significa que la ley pueda libremente determinar tal obligación (MARÍN LÓPEZ). Por ese mecanismo podría vaciarse el sistema de responsabilidad. Ciertamente la Administración no se lucra con el riesgo del desarrollo pero si causa daños tiene la obligación constitucional de reparar ese daño en tanto no sea modificado el artículo 106.2 CE. Que no haya lucro cuando la Administración causa daños mediando riesgos del desarrollo no nos parece un argumento decisivo. Lo decisivo es la ruptura del principio de igualdad ante las cargas públicas en detrimento de los afectados por los riesgos del progreso en el marco de un sistema objetivo de responsabilidad objetiva. Tampo-

45 GonzÁlez PÉREZ, Responsabilidad patrimonial de las Administraciones Públicas, Civitas, Madrid 1996, p. 274. 
DA-2003, núms. 265-266. JESÚS JORDANO FRAGA. Ciencia, Tecnología, medio ambiente y respons...

co hay lucro cuando la Administración causa daños en caso fortuito existiendo funcionamiento normal. Ésta es la diferencia entre responsabilidad y expropiación.

Creemos igualmente que si se acepta la premisa de que nuestra Constitución reconoce un sistema objetivo de responsabilidad es indiferente el encuadre de la cláusula de exoneración ${ }^{46}$. Nosotros sostenemos que la sola exclusión de la fuerza mayor en el artículo 106.2 es lo que consagra la objetividad del sistema. El artículo 106.2 confiere un amplio margen al legislador «en los términos establecidos por la ley» pero no le da un cheque en blanco. El artículo 106.2 CE congela el sistema al excluir sólo la fuerza mayor. Es un retrato robot mínimo pero con límites. Así, el artículo 106.2 CE no permite una opción legislativa sobre el sistema de responsabilidad que excluyera determinado tipo de bienes (p. ejem., los de propiedad urbana), pues incluye «toda lesión que sufran en cualesquiera de sus bienes y derechos». No debe resultar extraño que el constituyente consagrara el sistema de responsabilidad existente en nuestro ordenamiento en ese momento y vigente desde el artículo 121 LEF de 1954. Lo extraño hubiera sido lo contrario. Doctrinalmente esto lo han sostenido GARRIDO FALLA ${ }^{47}$, MARTÍN REBOLLO, o BELADIEZ $\mathrm{ROJO}^{48}$. En este momento habría que recordar que con fundamentos parecidos el TC ha impuesto soluciones concretas ex artículo $105 \mathrm{CE}$ aunque exista un reenvío al legislador.

Esta tesis es bien simple. Admitida esta premisa de la constitucionalización de un sistema objetivo de responsabilidad en el artículo

${ }^{46}$ Por lo demás, la Ley 4/1999 dice lo que dice, teniendo en este sentido la Exposición de Motivos valor interpretativo. La doctrina que ha discutido sobre los riesgos del desarrollo hasta la Ley 4/1999 ha encuadrado la problemática de los riesgos del desarrollo en los parámetros fuerza mayor/caso fortuito. No le sería dado al legislador alterar la naturaleza de las cosas. En cualquier caso -insistimos-, dada la objetividad del sistema, el debate es intranscendente.

47 «Lo que ha hecho, pues, este precepto es constitucionalizar los resultados ya alcanzados, a nivel de Ley ordinaria, por nuestro Derecho positivo» ( «La constitucionalización de la responsabilidad patrimonial del Estado», R.A.P., $\mathrm{n}^{\circ} 119$, mayo-agosto, 1989, p. 30).

48 Manejando argumentos en contra de la constitucionalización de un sistema objetivo en el art. 106.2 CE, véase Mir PUIGPELAT, La responsabilidad patrimonial de la Administración. Hacia un nuevo sistema, Civitas, Madrid 2002, pp. 215-222. Resulta curioso que el autor destaque la divergencia frente a la fórmula legislativa. Los debates (una vez incluida la enmienda de la UCD que, salvo la omisión inicial, no sufrió variaciones el texto) no permiten llegar a esta conclusión precipitada. Antes al contrario, la inexistencia de alusión al funcionamiento normal o anormal ha sido explicada por GUAITA, en el sentido de ser innecesaria la alusión al funcionamiento anormal (se parte de que al ser la responsabilidad objetiva va a existir responsabilidad con independencia de que el funcionamiento sea normal o anormal) (Comentarios a las Leyes políticas. Constitución española de 1978. Tomo VIII, arts. 97-112, (AlZaga VillaAmil, Óscar, Dir.), Madrid EDERSA 1985, p. 370. En este contexto, negar la constitucionalización del sistema desde la propia fórmula del 106.2 CE nos parece un desideratum. 
106.2 CE, que por cierto tiene amplio reflejo jurisprudencial, es indiferente la ubicación de la cláusula de exoneración. Si ésta es contraria al sistema objetivo constitucionalizado devendrá inconstitucional. La cobertura de la antijuricidad es, en este sentido, irrelevante. Pues bien, la cláusula de exoneración excluye la responsabilidad por daños donde no hay culpa y subjetiviza el sistema (DíEZ-PICAZO, LEGUINA VILla, ESTEVE PARDO). Esta operación es la que entendemos inconstitucional. Resultaría paradójico que en Francia, en un sistema subjetivo, se haya declarado la responsabilidad en estos supuestos con fundamento en la no recomendación de autotransfusión en intervenciones programadas -aquí se ha visto la culpa-y que nuestro sistema teóricamente objetivo de responsabilidad excluya con la nueva cláusula estos daños.

Creo que el debate ineludiblemente ofrecerá dos frutos: la síntesis anunciada en forma de sentencia del TC determinando el alcance del sistema de responsabilidad constitucionalizado y la necesidad de tallar legislativamente nuestro sistema de responsabilidad patrimonial de las Administraciones Públicas. Respetando los límites constitucionalizados, el legislador tiene por delante un reto de precisión, desarrollo detallado y concreción de los elementos del sistema que ciertamente no pueden quedar abandonados por entero a la construcción jurisprudencial. La polémica reseñada contribuye a sacar a la luz de forma decisiva esta necesidad.

\section{RESPONSABILIDAD POR DAÑOS AL MEDIO AMBIENTE Y RESPONSABILIDAD DE LA ADMINISTRACIÓN}

\section{A LOS RIESGOS TECNOLÓGICOS Y LAS ADMINISTRACIONES PÚBLICAS. EL PRINCIPIO DE PRECAUCIÓN O CAUTELA}

En los prolegómenos de este estudio hemos señalado como principio emergente el de cautela. Este principio está enunciado al más alto nivel en el artículo 174 TCEE (antiguo artículo $130 \mathrm{R}$ ).

2. «La política de la Comunidad en el ámbito del medio ambiente tendrá como objetivo alcanzar un nivel de protección elevado, teniendo presente la diversidad de situaciones existentes en las distintas regiones de la Comunidad. Se basará en los principios de cautela y de acción preventiva, en el principio de corrección de los atentados al medio ambiente, preferentemente en la fuente misma, y en el principio de quien contamina paga.» 
Este principio de cautela o precaución significa afirmar el principio in dubio pro natura en caso de incertidumbre científica ${ }^{49}$. Para su despliegue suelen exigirse los siguientes requisitos: 1. Incertidumbre científica; 2. Proporcionalidad y no discriminación; 3. Gravedad y urgencia; 3. Carácter transitorio; 4. Desarrollo ulterior de investigaciones destinadas a una evaluación más objetiva del riesgo; y, 5. Comunicación al público ${ }^{50}$. El despliegue del principio puede llevar a la prohibición de una actividad o a la adopción de medidas efectivas y proporcionadas destinadas a prevenir un riesgo de daño al ambiente ${ }^{51}$.

La jurisprudencia ha deducido que de los principios de cautela y de acción preventiva se desprende que el concepto de residuo no puede ser objeto de interpretación restrictiva (Sentencia de 15 de junio de 2000, ARCO Chemie Nederland y otros, asuntos acumulados C-418/97 y C419/97, Rec. p. I-4475, apartados 36 a 40). En virtud de los principios de cautela y acción preventiva, incumbe a la Comunidad y a los Estados miembros evitar, reducir y, en la medida de lo posible, suprimir, en el origen, las fuentes de contaminación o de daños mediante la adopción de medidas tendentes a eliminar los riesgos conocidos (véase la sentencia Lirussi y Bizzaro, de 5 de octubre de 1999, asuntos acumulados C175/98 y C-177/98, apartado $51^{52}$ ).

49 Según ReHBINDER, el significado del principio de precaución implica «que la política ambiental no está limitada a la eliminación o reducción de la contaminación ya existente o inminente (protección contra el peligro en contraposición al mero riesgo), sino que asegura que la contaminación es combatida de forma incipiente y que los recursos naturales son usados sobre la base de un rendimiento sostenido(«The Basic Constitutional, Institutional and Administrative Law Contexts», en el volumen colectivo Understanding US and European Environmental Law: A Practitioners Guide, Graham \& Trotman /Martinus Nijhoff, London 1989, pp. 12 a 14). Como dice SADELEER, este principio se inscribe dentro de una perspectiva dinámica y no estática. Las decisiones tomadas a su amparo deben ser consideradas revisables (debe poder prohibirse lo que se ha considerado autorizable o viceversa en función de la evolución de la información: «las decisiones de naturaleza irreversible están en las antípodas del principio de precaución» («Le principe de précaution: du slogan à la règle de Droit», Droit de l'environnement, $\mathrm{n}^{\circ}$ 77, avril 2000, p. 15). Aplicando esta última opción expresamente, C.E de 22 de enero de 1999 (insecticide Gaucho) -la autorización sobre comercialización de un pesticida nunca es definitivaRomI, «Droit de la santé, droit de l'environnement: intégrations croisées», en VV.AA., Les principes généraux du Droit de l'environnement, Droit de l'environnement $\mathrm{n}^{\circ} 90$ (numéro spécial), août 2001, p. 148. Sobre el principio de precaución véase, en especial, VV.AA., Le principe de précaution, numéro especial 2000 de la Revue Juridique de l'environnement.

50 Véanse KROMAREK, «Le principe de précaution vu par l'industrie» en VV.AA., Les principes généreaux du Droit de l'environnement, Droit de l'environnement $\mathrm{n}^{\circ} 90$ (numéro spécial), août 2001, pp. 189-191; ICARD, «L'articulation de l'ordre communautaire et des ordres nationaux dans l'application du principe de précaution», en VV.AA., Le principe de précaution, numéro especial 2000 de la Revue Juridique de l'environnement, pp. 38-40.

51 T.A Amiens, 30 de junio de 1999, Cne de Noyon. Vid. apud. FERru \& CANS, Les méandres du principe de précaution rectifiés par le juge administratif en VV.AA, Les principes généreaux du Droit de l'environnement, Droit de l'environnement n'90 (numéro spécial), août 2001, p. 187.

52 Y según el apartado 53 de esta sentencia, «En la medida en que los residuos, aun almacenados temporalmente, pueden causar daños importantes al medio ambiente, procede 
Hemos dicho que una adecuada utilización del principio de cautela puede tener como efecto la evitación de daños generados por riesgos del desarrollo. En este sentido, el principio de precaución, como ha dicho BAGHESTANI-PERREY, «es una norma de referencia indisociable del Derecho de responsabilidad $»^{53}$. La jurisprudencia contencioso administrativa comienza a enfrentarse con este principio. En sede de radiaciones electromagnéticas provocadas por líneas de alta tensión afirma que la carga de la prueba del peligro para el medio ambiente o la calidad de vida la tiene quien impugna las decisiones administrativas (STS de 14 abril 1998, Ar.1998\3633, Sala de lo Contencioso-Administrativo, Sección 3a, Ponente Ledesma Bartret, f. de dcho. $4^{\text {o54) }}$. La jurisdicción civil, en relación con la contaminación electromagnética generada por la telefonía móvil, está aplicando el principio de cautela y para adoptar medidas entiende bastante la prueba de la «sospecha razonable» o la «duda fundada»-que genera el informe elaborado por expertos británicos del IEGMO- (Sentencia del Juzgado de Primera Instancia $\mathrm{n}^{\mathrm{o}} 2$ de Bilbao, de 9 de junio de 2001, AC 2001/1812 Magistrado Juez, Herrera Cuevas), para declarar la nulidad de un acuerdo comunitario que ampara la instalación de una antena emisora de telefonía móvil en la azotea del edificio. En Francia, el principio de precaución consagrado legislativamente ha sido usado por los tribunales para anular decisiones administrativas u otorgar suspensiones de dichas decisiones ${ }^{55}$.

considerar que el artículo 4 de la Directiva 75/442, cuyo objetivo consiste en aplicar el principio de cautela, es igualmente aplicable a la operación de almacenamiento temporal».

53 «La valeur juridique du principe de précaution» en VV.AA., Le principe de précaution, numéro especial 2000 de la Revue Juridique de l'environnement, p. 26.

54 Cunto.- «El Tribunal ha examinado con especial atención, dada la extraordinaria importancia que tiene, el alegato referente a la repercusión negativa del acuerdo impugnado sobre la salud, el medio ambiente, la calidad de vida, la economía agrícola y ganadera, la creación de puestos de trabajo y la riqueza monumental. Sin embargo, salvo algunas afirmaciones contenidas en la breve exposición que se lleva a cabo en el apartado de hechos de la demanda, no hay en el expediente administrativo ni en los autos de este proceso, prueba que acredite la realidad de aquellas afirmaciones. Los «numerosos datos científicos de que disponemos hoy en día», por utilizar las propias expresiones de la demanda, los libros, publicaciones e investigaciones a que también se hace referencia de modo impreciso en este escrito, no han sido traídos al proceso por quien tenía la carga procesal de hacerlo (arts. 504 y 505 LECiv)». Por contra, en Italia se ha postulado en el ámbito electromagnético la inversión de la carga de la prueba (SCALIA, CEvolin).Véase la nota de Mateo Ceruti, «Inquinamento elettromagnetico», Rivista Giuridica dell'ambiente, 1, 2000, pp. 119134, en especial nota $\mathrm{n}^{\circ} 50$.

55 TA Lille, de 19 de abril de 2000, anulando $e x$ art. 122.1 del Code de l'urbanisme un Schéma directeur. Vid. BARALLE, «Risque avéré de pollution et principe de précaution», Droit de l'environnement, septembre 2000, no 81, pp. 9-81; CE de, 19 de febrero de 1998, Association Greenpeace Franc. Vid. SADELEER, «Le principe de précaution: du slogan à la règle de Droit», Droit de l'environnement, $\mathrm{n}^{\circ} 77$, avril 2000, pp. 14-15. 
DA-2003, núms. 265-266. JESÚS JORDANO FRAGA. Ciencia, Tecnología, medio ambiente y respons...

\section{B) La propuesta regulación de la responsabilidad por daños al medio ambiente}

En esta materia el referente ha venido constituido por el Libro Blanco sobre responsabilidad ambiental, presentado por la Comisión ${ }^{56}$. El Libro Blanco concluía que la opción más adecuada y preferible consistía en la adopción de una Directiva marco comunitaria que contemplara, por un lado, la responsabilidad objetiva por los daños ambientales derivados de actividades peligrosas reguladas por la legislación comunitaria (que cubriera, con circunstancias eximentes y atenuantes, tanto los daños tradicionales como los causados al medio ambiente) y que también regulara la responsabilidad por culpa en los casos de daños a la biodiversidad derivados de actividades no peligrosas. El Libro Blanco sobre responsabilidad ambiental no contemplaba la exclusión de los riesgos del desarrollo, pareciendo optar por un régimen de responsabilidad no degradable mediante supuestos de exención no tradicionales ${ }^{57}$.

El Libro Blanco aludía a los riesgos del desarrollo como causa de exoneración pero sólo como opinión expresada por los operadores económicos y reconociendo al propio tiempo que «las circunstancias eximentes y atenuantes de este tipo «no suelen aceptarse en los regímenes de responsabilidad ambiental vigentes en los Estados miembros de la Unión Europea ${ }^{58}$. De igual forma, como hemos visto, el Libro Blanco parecía descartar expresamente la exoneración para las actividades relacionadas con los organismos genéticamente modificados ${ }^{59}$.

Estos planteamientos han sido sorprendentemente superados por la Propuesta de Directiva del Parlamento y del Consejo sobre responsabilidad ambiental en relación con la prevención y reparación de daños ambientales ${ }^{60}$. La Propuesta aludida contempla como excepciones en su artículo 9 las siguientes:

1. «Sin perjuicio de lo dispuesto en el artículo 10, la presente directiva no contemplará daños ambientales o una amenaza inminente de causar estos daños debidos a

a) un acto derivado de un conflicto armado, hostilidades, guerra civil o insurrección;

56 Bruselas 9-2-2000 COM (2000) 66 final, ISSN 0257-9545, No de catálogo: KT-CO00-66-ESC-C, Oficina de Publicaciones Oficiales de las Comunidades Europeas, L-2985, Luxemburgo.

57 Cfr. Libro Blanco sobre responsabilidad ambiental, pp. 4,10, 18 y 30.

58 Cfr. Libro Blanco sobre responsabilidad ambiental, p. 19.

59 Cfr. Libro Blanco sobre responsabilidad ambiental, p. 17.

60 Bruselas 23 de enero de 2001 COM (2001) 17 final (2002/0021 (COD). Puede verse en http://europa.eu.int/eur-lex/es/index/html/. 
b) un fenómeno natural de carácter excepcional, inevitable e irresistible;

c) una emisión o acto permitidos en las leyes y reglamentos aplicables o en el permiso o la autorización expedidos al operador:

d) emisiones o actividades que no se hayan considerado perjudiciales de acuerdo con el estado de los conocimientos científicos y técnicos en el momento en que se produjo la emisión o tuvo lugar la actividad ${ }^{61}$.

Resulta realmente llamativa la incorporación de esta solución aprobada durante la Presidencia española de la UE. En materia de riesgos del desarrollo se ha adoptado la solución demandada por los agentes económicos (asociaciones industriales y profesionales) que básicamente reclamaban un régimen basado en la culpa, sin atenuación de carga de la prueba y que rechace la solidaridad ${ }^{62}$. Un punto insistente en la postura de las asociaciones industriales y profesionales ha sido el que fuera considerado como circunstancia exoneradora de responsabilidad el estado de la ciencia y de la técnica ${ }^{63}$. Supongo que estoy anticuado: veo inadmisible que en esto se haya cedido ante la posición de los empresarios. No sólo es inadmisible en términos éticos que los sujetos regulados ganen en sus pretensiones frente a la colectividad de ciudadanos europeos. Creo que en el caso la solución adoptada es inconsistente e ilógica. Así, por ejemplo, los parágrafos quinto y sexto de la Ley alemana de 10 de diciembre de 1990 (Umwelthaftungsgesetz), no comprenden los riesgos del desarrollo lo que precisamente ha sido considerado una novedad respecto de la Produkthaftungsgesetz ${ }^{64}$. El Propio Libro blanco previamente había constatado la necesidad de un régimen divergente:

«Además, aunque algunas de estas actividades (como las relativas a los organismos modificados genéticamente) no son intrín-

${ }^{61}$ Curiosamente el art. 4. 2, letra a) del Anteproyecto de Ley de responsabilidad civil derivada de actividades con incidencia ambiental presentado por el Ministerio de Medio Ambiente en el III Congreso Nacional de Derecho Ambiental de Barcelona establecía:

«No existirá responsabilidad en los siguientes supuestos:

Cuando el daño o deterioro del medio ambiente se derive de hechos o circunstancias que no se hubieran podido prever o evitar según el estado de conocimiento de la ciencia o de la técnica existentes en el momento de producción de aquellos».

62 Siendo nefasta la Propuesta adoptada en lo que a los riesgos del desarrollo se refiere, debe elogiarse la transparencia del proceso.

63 Propuesta de Directiva del Parlamento y del Consejo sobre responsabilidad ambiental en relación con la prevención y reparación de daños ambientales, p. 30.

64 Vid. Pozzo, «Verso una responsabilità civile per danni all'ambiente in Europa: Il nuovo» Libro Bianco della Commissione delle Comunità «europee», $R G A, 2000$, p. 635 y nota $\mathrm{n}^{\mathrm{o}} 41$. 
DA-2003, núms. 265-266. JESÚS JORDANO FRAGA. Ciencia, Tecnología, medio ambiente y respons...

secamente peligrosas, pueden provocar, en determinadas circunstancias, daños a la salud o importantes daños al medio ambiente. Tal podría ser el caso, por ejemplo, si se produjera un escape en una instalación de confinación de alto nivel o si se derivaran consecuencias imprevistas de una liberación intencional. Por ese motivo, se considera adecuado que dichas actividades estén incluidas en el ámbito de un régimen de responsabilidad de alcance comunitario. Sin embargo, la definición específica de algunos de los elementos del régimen (como, por ejemplo, el tipo de circunstancias eximentes aceptadas) podría no ser la misma en todos los casos de actividades relacionadas con organismos genéticamente modificados, por lo que tendrían que establecerse diferencias en función de la legislación aplicable y de las actividades de que se trate» (Cfr. Libro Blanco sobre responsabilidad ambiental, p. 17).

Creemos igualmente que la introducción de esta causa de exoneración choca con el principio de precaución consagrado en el artículo 174 TCEE (así, LAMBERT-FAIVRE). Esto admitimos que es discutible (GUÉGAN). Pero lo que no es discutible es que de admitirse esta exoneración, la propia norma debiera prever un fondo para la indemnización ${ }^{65}$.

Ciertamente, la admisión de esta causa de exoneración choca con el propio ámbito de la propuesta de Directiva, al menos, en lo que se refiere a los organismos modificados genéticamente. La Propuesta de Directiva incluye dentro de su ámbito de aplicación (Anexo I) «Toda utilización confinada, incluida el transporte, de microorganismos modificados genéticamente, de acuerdo con la definición y el ámbito de aplicación de la Directiva 90/219/CEE del Consejo de 23 de abril de 1990, relativa a la utilización confinada de microorganismos modificados genéticamente» $\mathrm{y}$ «toda liberación intencional en el medio ambiente o transporte de organismos modificados genéticamente de acuerdo con la definición y el ámbito de aplicación de la Directiva 2001/18/CE del Parlamento Europeo y del Consejo de 12 de marzo de 2001. Pero paralelamente configura los riesgos del desarrollo como causa exención

65 En este sentido GUÉGAN siguiendo en esto a HUET, «L'apport du principe de précaution au droit de la responsabilité civile», Revue Juridique de l'environnement $\mathrm{n}^{\circ} 2,2000$, $\mathrm{p}$. 177. La propuesta de directiva examinada sólo determina tímidamente que, sin perjuicio de la exclusión, los Estados miembros garantizarán que se adopten las medidas preventivas o de reparación (art. 6). No creemos admisible esta causa de exoneración, pero de admitirse debiera ir acompañada de un régimen cierto de reparación con cargo a un fondo cierto, concreto y dotado financieramente. El problema es muy parecido al examinado en relación con el art. 141.1, que de facto desplaza a las víctimas los daños (como ha ocurrido ya hasta el momento en relación con la hepatitis $\mathrm{C}$ ). 
DA-2003, núms. 265-266. JESÚS JORDANO FRAGA. Ciencia, Tecnología, medio ambiente y respons...

de responsabilidad en la misma propuesta en los términos ya vistos (art. 9 de la Propuesta de Directiva). Pues bien, respecto de la actividad de ingeniería genética, carece de lógica la afirmación de esta causa de exención de responsabilidad. Porque, ¿cuáles son los daños ambientales que puede producir la ingeniería genética que no son riesgos del desarrollo? ${ }^{66}$. La paradoja total es que, según el considerando 16 de la Directiva 2001/18 CE del Parlamento y del Consejo, de 12 de marzo de 2001 sobre liberación intencional en el medio ambiente de organismos modificados genéticamente ${ }^{67}$, esta propuesta estaba destinada a regular en nivel europeo la responsabilidad por daños ambientales de los OGM. Vaya regulación !!!

Desde un punto de vista estratégico, creemos que este tipo de decisiones sólo pueden alentar la tecnofobia y alarma ciudadana. Si tan inocuos son los OGM, ¿qué necesidad hay de introducir esta cláusula de «patente de corso» a instancias de los empresarios? Confío en que la sensatez se imponga y las aguas vuelvan a su cauce en la tramitación de esta Propuesta de Directiva. Quede claro que no nos oponemos al desarrollo de esta tecnología. Nos oponemos a que si esta tecnología causa daños desconocidos en el actual estado de la ciencia, las empresas que legítimamente quieran enriquecerse con ella sean irresponsables ${ }^{68}$. Curioso negocio el de estas empresas que no socializan sus beneficios y pretenden -con el insólito apoyo de la UE-socializar sus potenciales riesgos. En una sociedad avanzada como la nuestra esa protección de la innovación no tendría como fin último la preservación de intereses superiores como la vida o la supervivencia de la colectividad (conjurar males y peligros -ESTEVE PARDO-), sino meramente el interés económico de determinadas sociedades. Éste sería el supuesto de los organismos modificados genéticamente, o el de las radiaciones electromagnéticas. Es obvio que la vida sin soja transgénica es posible (lo de vivir sin móviles, ciertamente, empieza a ser más una discutible y soñada utopía). El balance de intereses en conflicto es pues entre intereses privados (o en segunda línea intereses económicos de la sociedad que se beneficia económicamente de dicha actividad) e intereses en primera línea de la sociedad (interés a la reparación ambiental y prevención general derivada de esa posible obligación de reparación de los daños que se causen). Para no-

${ }^{66}$ Conforme a la actual redacción de la propuesta de Directiva sólo habrá responsabilidad en los supuestos de daños con dolo o culpa pues de acuerdo con el apartado 2 del art. 9 la excepción no se aplica si el operador ha actuado con negligencia. Esto de facto inmuniza a los operadores frente a los denominados riesgos del desarrollo o del progreso.

${ }^{67}$ DOCE número L, de 17 de abril de 2001.

68 En idéntico sentido, respecto de la responsabilidad por productos defectuosos, LóPEZ MENUDO, «Responsabilidad administrativa y exclusión de los riesgos del progreso. Un paso adelante en la definición del Sistema», cit., p. 25. 
sotros no hay duda de la prevalencia de los intereses ambientales de la sociedad en su conjunto.

\section{ADDENDA}

Este estudio fue cerrado en septiembre de 2002. Un año después la Directiva a la que se alude en el trabajo ha sufrido importantes modificaciones tras la primera lectura del PE y la posición común del Consejo de 18 de septiembre de 2003. A diferencia de la propuesta de la Comisión, la posición común no excluye del ámbito de aplicación de la futura directiva los daños causados por emisiones o hechos expresamente autorizados ni los daños causados por emisiones o actividades que no fueron consideradas perjudiciales de acuerdo con el estado de conocimientos científicos y técnicos en el momento en que se liberó la emisión o se desarrollo la actividad. No obstante, en tales casos los Estados miembros pueden permitir que el operador no sufrague el coste de las medidas reparadoras, siempre que demuestre que el hecho, la emisión o la actividad causantes del daño están cubiertos por algunas de las circunstancias antes mencionadas y no ha habido falta o negligencia por su parte (apartado 4 del artículo 8).

\section{BIBLIOGRAFÍA}

BARALLE, Pierre-Jean, «Risque avéré de pollution et principe de précaution» Droit de l'environnement, septembre 2000, núm. 81, pp. 9-81.

CERUTI, Mateo, «Inquinamento elettromagnetico», Rivista Giuridica dell'ambiente, 1, 2000, pp. 119-134.

ChADELAT, Catherine, «Risque de développement», Revue Générale du Droit des Assurances, 1998, núm. 3, pp. 452-461.

COMINGES CÁCERES, Francisco, «Análisis jurisprudencial de la responsabilidad administrativa por contagio de hepatitis C», Revista de Administración Pública núm. 155, mayo-agosto 2001, pp. 193-222.

DESDENTADO DAROCA, Eva, «Reflexiones sobre el artículo 141.1 de la Ley 30/1992 a la luz del análisis económico del Derecho», R.E.D.A. núm.108, octubre-diciembre 2000, pp. 533-563.

DíeZ-Picazo y PONCE DE LEÓn, Luis, Derecho de Daños, Civitas, Madrid 1999.

ESTEVE PARDO, José, Técnica, Riesgo y Derecho. (Tratamiento del riesgo tecnológico en el Derecho ambiental), Ariel Derecho, Ed. Ariel S.A., Barcelona 1999. 
DA-2003, núms. 265-266. JESÚS JORDANO FRAGA. Ciencia, Tecnología, medio ambiente y respons...

- «La adaptación de las licencias a la mejor tecnología disponible», Revista de Administración Pública, núm. 149 mayo-agosto 1999, pp. 37-61.

GARCÍA-ÁLVAREZ, Gerardo, «La responsabilidad extracontractual de la Administración y de su personal en el Derecho comparado», Revista Aragonesa de Administración Pública núm. 18, junio 2001, pp. 405-433.

GARCÍA DE ENTERRÍA, Eduardo y FERNÁNDEZ RODRÍGUEZ, TomásRamón, Curso de Derecho Administrativo, 7 ed., Civitas, Madrid 2000.

GARCÍA GÓMEZ DE MERCADO, Francisco, «La responsabilidad patrimonial tras la Ley 4/1999», Actualidad Administrativa núm. 32, 6 al 12 de septiembre de 1999, pp. 893-907.

GUÉGAN, Anne, «L'apport du principe de précaution au droit de la responsabilité civile», Revue Juridique de l'environnement núm. 2, 2000, pp. 147-178.

JORDANO FRAGA, Jesús, «La reforma del artículo 141, 1, apartado 1, de la Ley 30/1992, de 26 de noviembre, o el inicio de la demolición del sistema de responsabilidad objetiva de las Administraciones Públicas», Revista de Administración Pública, núm. 149 mayo-agosto 1999, pp. 321-336.

- La reparación de los daños catastróficos (Catástrofes Naturales, Administración y Derecho público: responsabilidad, seguro y solidaridad), Marcial Pons 2000.

LEGUINA VILLA, Jesús, «La reforma de la Ley de Procedimiento», Justicia Administrativa, núm. 7, abril 2000, pp. 7-13.

LÓPEZ MENUDO, Francisco, «Responsabilidad administrativa y exclusión de los riesgos del progreso. Un paso adelante en la definición del Sistema», Revista Andaluza de Administración Pública núm. 36, octubre-noviembre-diciembre 1999, pp. 11-44.

MARÍN LÓPEZ, Juan José, Daños por productos: estado de la cuestión, Tecnos, Madrid 2001.

MARTÍN REBOLLO, Luis, «Ayer y hoy de la responsabilidad patrimonial de la Administración: un balance y tres reflexiones», Revista de Administración Pública núm. 150, septiembre-diciembre 1999, pp. 317-371.

MIR PUIGPELAT, Oriol, «La reforma del sistema de responsabilidad patrimonial de las Administraciones Públicas operada por la Ley 4/1999, de 13 de enero, de modificación de la LRJPAC», Revista Jurídica de Catalunya, núm. 4, Any XCVIII, 1999, pp. 49-90.

- La responsabilidad patrimonial de la Administración sanitaria. Organización, imputación y causalidad, Civitas, Madrid 2000.

- La responsabilidad patrimonial de la Administración. Hacia un nuevo sistema, Civitas, Madrid 2002. 
DA-2003, núms. 265-266. JESÚS JORDANO FRAGA. Ciencia, Tecnología, medio ambiente y respons...

Montoro Chiner, María Jesús \& Hill Prados, María Concepción, Responsabilidad patrimonial de la Administración y contrato de seguro, Atelier administrativo, Barcelona 2002.

PELAYO PARDOS, Santiago, «Sida, hepatitis y artículo 37 de la Ley 4/1999 de modificación de la Ley 30/1992». La teoría de los riesgos del desarrollo, D 68, La Ley 1999, tomo 2, pp. 1709-1712.

PÉREZ GÁLVEZ, Juan Francisco, «Responsabilidad por acto sanitario y progreso de la "ciencia" o de la "técnica"», Revista Española de Derecho Administrativo, núm. 104, octubre-diciembre, 1999, pp. 657673.

PÉREZ MONGUIÓ, José María, «Fuerza mayor en la responsabilidad extracontractual de la Administración Pública», Revista Aragonesa de Administración Pública núm. 18, junio 2001, pp. 357-376.

PÉREZ-TENESSA, Antonio, «Sobre el diagnóstico prenatal como causa de responsabilidad», Revista de Administración Pública núm. 154, enero-abril 2001, pp. 47-61.

POZZO, Barbara, «Verso una responsabilità civile per danni allambiente in Europa: Il nuovo Libro Bianco della Commissione delle Comunità eropee», Rivista Giuridica dell'ambiente, 2000, pp. 623-664.

SADELEER, Nicolas De, «Le principe de précaution: du slogan à la règle de Droit», Droit de l'environnement, núm. 77, avril 2000, pp.1415.

SALVADOR CODERCH, Pablo y SOLÉ FELIU, Josep, Brujos y aprendices (Los riesgos del desarrollo en la responsabilidad del producto), Ed. Marcial Pons, Madrid 1999.

VVAA., Comentarios a las Leyes políticas. Constitución española de 1978. Tomo VIII, arts. 97-112, (ALZAGA VILLAAMIL, Óscar, Dir.), EDERSA, Madrid 1985.

V.AA., Jornadas de Estudio sobre la Reforma de la Ley 30/1992, B.O.E, serie Administración General, Madrid 1997.

V.AA., «Responsabilidad por daños en el tercer milenio», Homenaje al Profesor Doctor Atilio Aníbal Alterini (Alberto José BUERES \& Aida Kemelmajer DE CARLUCCI, Dir.), Abeledo-Perrot, Buenos Aires 1997.

VV.AA., La responsabilidad patrimonial de las Administraciones Públicas, BELlO JANEIRO, Domingo (Dir.),Colección Xornadas e seminarios núm. 22, EGAP, Santiago de Compostela, 1999.

V.AA., «Le principe de précaution», numéro especial 2000 de la Revue Juridique de l'environnement.

V.AA., «Les principes généraux du Droit de l'environnement», Droit de l'environnement núm. 90 (numéro spécial), août 2001. 